\title{
Discrimination in digital immigration status
}

\author{
Joe Tomlinson ${ }^{1 \star}$ (D), Jack Maxwell ${ }^{2}$ and Alice Welsh ${ }^{3 \dagger}$ \\ ${ }^{1}$ University of York, York, UK, ${ }^{2}$ Public Law Project and ${ }^{3}$ University of York, York, UK \\ ${ }^{\star}$ Corresponding author email: joe.tomlinson@york.ac.uk
}

(Accepted 16 May 2021)

\begin{abstract}
The UK has recently adopted a policy of granting digital-only proof of immigration status for certain groups of migrants. More than 4.5 million individuals are reliant on this form of status and the number is growing. In this paper, we argue that this policy, as currently operationalised, is unlawful as a result of its discriminatory impact. If it remains unchanged, the roots of digital discrimination in immigration policy and administration will be allowed to spread, with potentially disastrous consequences.
\end{abstract}

Keywords: immigration; digital administration; equality law; discrimination; public law

'The sincerity of [the] apology will be determined by how far the Home Office demonstrates a commitment to learn from its mistakes by making fundamental changes to its culture and way of working, that are both systemic and sustainable'.

- Windrush Lessons Learned Review (HC 93, March 2020).

\section{Introduction}

It is difficult to imagine a more important document than one which proves the entitlement to reside in a particular state: it is used as the manifestation of the 'right to have rights'. ${ }^{1}$ This was vividly illustrated recently by the infamous Windrush scandal, which saw - on the basis of problems proving the right to reside - lawful residents of the UK wrongly detained, denied legal rights, threatened with deportation, and, in at least 83 instances, deported from a country they were entitled to call home. $^{2}$ The Home Office, following an extensive review, promised to learn lessons. ${ }^{3}$

By 31 March 2021, there were almost 4.5 million individuals reliant on digital-only proof of their entitlement to reside lawfully in the UK. ${ }^{4}$ In practice, this means that those individuals can only access and share proof of their immigration status online, including when they want to rent a property or apply for a job. Based on government strategy, the number of people with digital-only proof

\footnotetext{
${ }^{\dagger}$ We are grateful for detailed and helpful comments from Tarun Khaitan, Sofia Ranchordas, Charlotte O’Brien, Christiaan van Veen, Bijan Hoshi, Elizabeth O'Loughlin, and the anonymous reviewers. Any errors or omissions remain our own.

${ }^{1} \mathrm{H}$ Arendt The Origins of Totalitarianism (NYC: Schocken Books, 1951) ch 9.

${ }^{2}$ For an account of the suffering that resulted see A Gentleman The Windrush Betrayal: Exposing the Hostile Environment (London: Guardian Faber, 2019).

${ }^{3}$ W Williams Windrush Lessons Learned Review, HC 93, 19 March 2020.

${ }^{4}$ By 31 March 2021, 4,977,740 people were granted settled or pre-settled status under the EU Settlement Scheme - a Home Office scheme which uses digital-only status. Non-EEA nationals are currently provided with a biometric residence card once they have been granted status under this scheme. Of these concluded applications, 4,689,660 are EEA nationals who are reliant on a digital-only proof of this status. There is a grace period under which they do not have to rely on digital status, but this came to an end on 1 July 2021.

(c) The Author(s), 2021. Published by Cambridge University Press on behalf of The Society of Legal Scholars. This is an Open Access article, distributed under the terms of the Creative Commons Attribution licence (http://creativecommons.org/licenses/by/4.0/), which permits unrestricted re-use, distribution, and reproduction in any medium, provided the original work is properly cited.
} 
of status will increase significantly in the coming years. ${ }^{5}$ This represents a major turning point in the emergence of digital administration, both generally and in the context of immigration policy. ${ }^{6}$ Politically, the policy has been controversial - being the subject of multiple pressure group campaigns and leading to a confrontation between the House of Lords and the House of Commons. ${ }^{7}$

Our central argument in this paper is that digital-only status - at least in its current, blanket form is unlawful because it is indirectly discriminatory. ${ }^{8}$ Using the EU Settlement Scheme (EUSS) as a case study, we show in detail how digital-only status disadvantages various groups with protected characteristics - namely, disability, age and race - in a way that is not proportionate to its underlying objectives. ${ }^{9}$ This argument has profound consequences both for the current operation of digital-only status in the EUSS, and for the Government's plans to roll it out across the broader immigration system. Ultimately, without adjustment, the policy risks separating people from their proof of residence, further extending discriminatory practices already within the immigration system, ${ }^{10}$ and giving rise to a digital version of the Windrush scandal.

We make this argument in four parts. First, we introduce how digital-only status operates, which is necessary to understand why its effects are discriminatory and thus unlawful. Secondly, we show - using three composite profiles with different protected characteristics - how digital-only status, at least in its current form, can seriously disadvantage certain groups of people. Thirdly, we argue that all attempts to eliminate these disadvantages have been inadequate. Finally, we show that the policy justifications for digital-only status do not sufficiently justify its discriminatory effects and, moreover, less discriminatory measures that achieve the same objectives are available.

\section{Digital-only status: the case of the EUSS}

It is important to begin by setting out clearly how digital-only status works. We focus on a specific case study - digital-only status within the EUSS - for two reasons. First, the discriminatory effects of digital status are rooted in the details of its design and implementation. It is possible to imagine such a policy being operationalised in different ways, some of which may well be lawful. It is helpful, therefore, to anchor the legal analysis of digital status in a specific case. Secondly, at present, the EUSS is most prominent example of digital status in the UK. It is embedded in a new and ambitious immigration scheme which has given status to approximately 4.5 million EEA nationals. This digital-only status is the only proof of an individual's right to enter, stay, work, rent and access services in the UK and will

\footnotetext{
${ }^{5} \mathrm{HM}$ Government The UK's future skills-based immigration system $\mathrm{Cm}$ 9722, December 2018, $\mathrm{p}$ 70. This is also an international trend, see A Beduschi 'Digital identity: contemporary challenges for data protection, privacy and non-discrimination rights' (2019) BD\&S 1.

${ }^{6}$ On the significance of this shift, see generally $\mathrm{H}$ Dijstelbloem Borders as Infrastructure: The Technopolitics of Border Control (MIT Press, 2021); J Tomlinson and J Maxwell Experiments in Automating Immigration Systems (Bristol: Bristol University Press, 2021).

${ }^{7}$ The campaign group the3million led the \#deniedmybackup campaign and the House of Lords passed an amendment to the Immigration and Social Security Co-ordination (EU Withdrawal) Bill, which required the provision of physical proof of status, but the amendment was later removed.

${ }^{8}$ For a fuller discussion of the policy arguments, see A Welsh and J Tomlinson 'Will digital immigration status work? (2020) 34(4) IANL 306.

${ }^{9}$ This argument could be put in terms of either the Equality Act 2010, specifically ss 4, 5, 6, 9, 19, 29(6) and 31(4), or the Human Rights Act 1998 and the ECHR, specifically Art 8, Art 14 and Art 1 of the First Protocol, together with authorities such as Thlimmenos $v$ Greece (2000) 31 EHRR 15 and DH v Czech Republic (2008) 47 EHRR 3. The substantive analysis - the discriminatory effects of digital-only status and the Government's justifications for it - would be much the same on either approach. For reasons of space, however, our analysis in this paper is confined to the substantive argument that digital-only status is indirectly discriminatory under the Equality Act 2010.

${ }^{10}$ This has been explored in recent scholarship: see eg S Guentner et al 'Bordering practices in the UK welfare system' (2016) 36(3) Critical Social Policy 391; J McHale and E Speakman 'Charging "overseas visitors" for NHS treatment, from Bevan to Windrush and beyond' (2020) 40(4) Legal Studies 565; C O’Brien Unity in Adversity: EU Citizenship, Social Justice and the Cautionary Tale of the UK (London: Bloomsbury, 2017).
} 
stay with them for many years, potentially their lifetime, unless they decide to naturalise as a British citizen in the future. It is also likely to be the template for the Government's planned expansion of this mode of status in the coming years. Problems with digital status within the EUSS are likely to flow through to the broader immigration system in the near future. It is this scheme that we refer to and focus our analysis upon in the remainder of this paper. ${ }^{11}$

The EUSS is the system established to allow EU citizens to apply to remain in the UK after Brexit. ${ }^{12}$ The Withdrawal Agreement between the EU and the UK requires this new residence status to be accompanied with a document evidencing that status and makes clear that the proof 'may be in a digital form'. Through the EUSS, the UK opted to provide European Economic Area (EEA) and Swiss nationals who get settled or pre-settled status with both confirmation and proof of their status in digital-only form. ${ }^{14}$ When status is granted, applicants are notified by an automatically generated email notification. This message itself is not proof of status but only a notification. Proof of status can only be accessed online. In principle, a person can access their status anywhere (if they have the technology and internet) and at any time by logging into the relevant government webpage. ${ }^{15}$ Individuals can also share their status with others who may need to see it, including employers and landlords. For EEA nationals, the EUSS is strictly digital-only; nobody receives an alternative form of status. As the Home Office puts it, digital status means that ' $[\mathrm{e}]$ vidence of... status will be given to EU citizens in digital form; no physical document will be issued to them. They will control who they wish to share this with'. ${ }^{16}$ By 31 March 2021, 4,689,660 EEA nationals held settled or pre-settled status and were thus within the digital-only status policy. This represented approximately $6.9 \%$ of the UK population at the time.

While the EUSS is the most prominent and largest deployment of digital status to date, it is clear that government strategy is to rely on this mode of status much more widely in the future. Policy statements around the replacement of EU free movement rules have made this clear. The Government's White Paper on The UK's future skills-based immigration system stated that:

Online status checking services will continue to be developed to allow individuals to share their status with employers, landlords and other service providers who have legal responsibility for confirming an individual's status. This approach will remove the current reliance on individuals having to produce documentary evidence of their status, or service providers having to interpret a myriad of documents. ${ }^{17}$

Baroness Williams, a Home Office Minister, recently confirmed this long-term intention to Parliament:

\footnotetext{
${ }^{11}$ The focus of our analysis is indirect discrimination, as that is the central equality issue pertaining to digital immigration status generally. However, it is important to note that, in the specific context of the EUSS, the same risks of discrimination we identify could arguably amount to direct discrimination on the grounds of nationality and conflict with the equal treatment provisions in Art 18 of the Treaty on the Functioning of the European Union. Article 12 of the Agreement on the withdrawal of the United Kingdom of Great Britain and Northern Ireland from the European Union and the European Atomic Energy Community (2019/C $384 \mathrm{I} / 01$ ) extends this protection to all who fall within the scope of the Agreement (see further Fratila $v$ Secretary of State for Work and Pensions [2020] EWCA Civ 1741). The imposition of a digital-only immigration status on all EEA and Swiss nationals who must apply to the EUSS could be, as we show, considered an express and disadvantageous distinction compared to UK nationals.

${ }^{12}$ Successful applicants to the scheme are awarded either settled status (indefinite leave to remain) if they can evidence residence in the UK for five continuous years or pre-settled status (limited leave to remain) if they have proof of residence of less than five continuous years. Pre-settled status only lasts for five years and those with this status must re-apply for settled status once they meet the requirements.

${ }^{13}$ Agreement on the withdrawal of the United Kingdom of Great Britain and Northern Ireland from the European Union and the European Atomic Energy Community [2019] OJ C 384I/01, Art 18(1) (emphasis added).

${ }^{14}$ Third country nationals who qualify for status under the EUSS receive physical proof of this in the form of a biometric residence card.

${ }^{15}$ Home Office 'View and prove your immigration status', available at www.gov.uk/view-prove-immigration-status.

${ }^{16}$ Home Office EU Settlement Scheme: Statement of Intent (21 June 2018) para 7.2.

${ }^{17} \mathrm{HM}$ Government, above n 5, p 70.
} 
Moving to online services is part of our declared aim of moving to a system which is digital by default, whereby all migrants, not just EEA citizens, will have online access to their immigration status, rather than having physical proof. ${ }^{18}$

This planned expansion of the use of digital status is part of a package of data infrastructure development in immigration administration. The design of the EUSS is the forerunner in this respect; digital-only status is just one part of a wider digital design. ${ }^{19}$ Under the EUSS system, applications for settled or pre-settled status are made online and then processed through an automated decisionmaking system built on extensive data-sharing arrangements between the Home Office, the Department for Work and Pensions, and HM Revenue \& Customs. This strategy also requires more extensive data linkage across departments and other actors, through which digital status is expected to facilitate '[r] eal time verification of status [that] will give other government departments and delivery partners, including employers and landlords, the tools to establish genuine, lawful, residence and rights. ${ }^{20}$ Digital status, for those who hold it, will be an essential pass through an increasingly digitalised landscape of public services.

Digital-only status is routinely practically significant to individuals who rely on it because people need to prove their immigration status not only to enter or leave the UK, but also to rent a house, find a job, open a bank account, or access healthcare and social security. The 'hostile environment' policy, now referred to by the government as the 'compliant environment,' also requires a range of third parties - landlords, employers, bankers, healthcare workers, police and other public officials - to check the immigration status of people they engage with. ${ }^{21}$ Such checks are already in operation and proving controversial, ${ }^{22}$ and digital-only status further significantly changes how people access and prove their status and thus changes the dynamics of these interactions. In practical terms, when asked to prove their entitlement to reside in the UK, people reliant on digital status have to take a series of steps. By way of example, Figure 1 sets out the steps required of a holder of digital-only status when proving their status for the purpose of a new job. Figure 2 sets out the actions required of the employer in the same situation. It is important for us to illustrate what these steps are in granular detail because, as we show in the next part of this paper, the mechanics of the process contribute to the overall discriminatory effects of the policy.

\section{Indirectly discriminatory effects}

In the context of the EUSS, digital-only status has been adopted as a blanket policy. From the time of its original policy statement on the EUSS in June 2018, the Home Office has maintained this position. ${ }^{23}$ To be clear, this is a policy choice: no law expressly requires the UK Government to provide digital-only status under the EUSS. ${ }^{24}$ There have been numerous warnings about the various risks inherent in this choice and the need for a more flexible approach. ${ }^{25}$ Yet, the policy has been

\footnotetext{
${ }^{18}$ Hansard HL Deb, vol 806, col 467, 5 October 2020.

${ }^{19}$ For an overview and analysis of this wider design, see J Tomlinson 'Justice in automated administration' (2020) 40(4) OJLS 708.

${ }^{20} \mathrm{HM}$ Government, above n 5, p 74. See also Independent Chief Inspector of Borders and Immigration An inspection of Home Office (Borders, Immigration and Citizenship System) collaborative working with other government departments and agencies: February - October 2018 (January 2019) paras 5.26-5.27.

${ }^{21} \mathrm{~A}$ Qureshi et al 'Access denied: the human impact of the hostile environment' (Institute for Public Policy Research, 3 September 2020).

${ }^{22}$ Including in terms of their discriminatory effects and their legality, see eg $R$ (Joint Council for the Welfare of Immigrants) $v$ Secretary of State for the Home Department [2019] EWHC 452 (Admin); Secretary of State for the Home Department $v R$ (Joint Council for the Welfare of Immigrants) [2020] EWCA Civ 542.

${ }^{23}$ Home Office, above n 16, para 7.2.

${ }^{24}$ Art $18(1)$ of the Withdrawal Agreement authorises, but does not require, the UK Government to provide EU citizens with evidence of their status 'in a digital form'. The Withdrawal Agreement has direct effect in UK law under the European Union (Withdrawal) Act 2018, s 7A.

${ }^{25}$ For example, multiple parliamentary committees have called on the Home Office to change its approach: House of Commons Exiting the European Union Committee The progress of the UK's negotiations on EU withdrawal: the rights of
} 


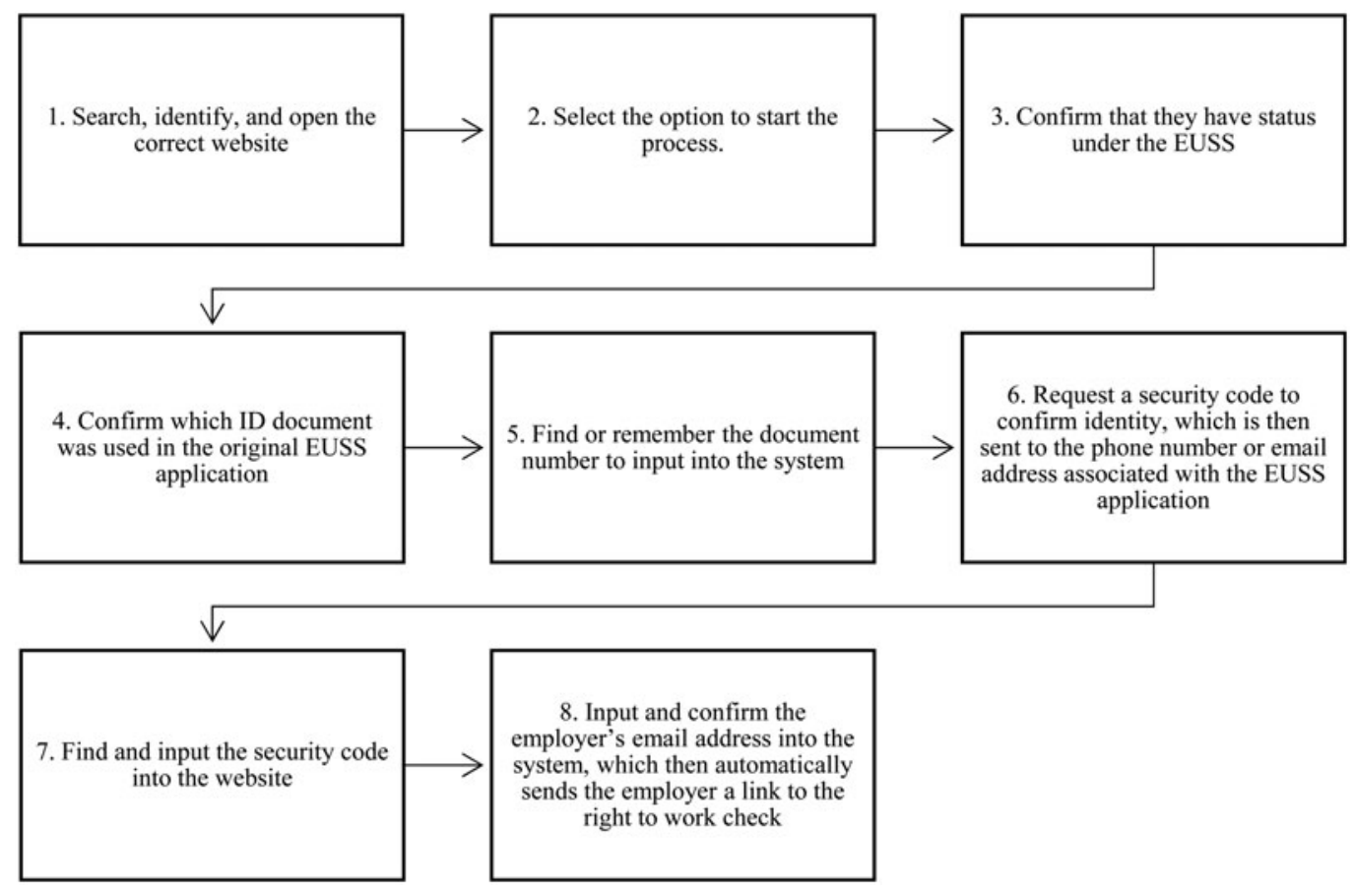

Figure 1. Steps required of digital status holder to prove status for the purposes of employment

maintained for all EEA and Swiss nationals granted status under the EUSS, irrespective of whether they have protected characteristics or might face difficulties in accessing or using digital status.

The Home Office claims that the digital-only status policy positively benefits vulnerable groups. ${ }^{26}$ One such claim is that some vulnerable groups, such as the elderly, are rarely required to prove their status and maintaining paper documents thus presents 'an additional level of bureaucracy' for them. ${ }^{27}$ Another example relied on is that visually impaired and dyslexic people may have difficulties reading a physical document. ${ }^{28}$ It is clear that digitalisation has the potential to help some individuals, including vulnerable individuals, better engage with public services. ${ }^{29}$ However, it is also clear that the policy has the potential to seriously disadvantage people and groups who are digitally excluded, and ultimately frustrate their rights and entitlements under law.

We focus on three groups of EU citizens: disabled people, older people, and Gypsy, Roma and Traveller people. $^{30}$ To show how digital-only status disproportionately affects these groups, we begin with the

UK and EU citizens Eighth Report of Session 2017-19, HC 1439, 9 December 2018, paras 38-49; Letter from the Chairman of the EU Justice Sub-Committee to the Home Secretary 'EU Settlement Scheme' (27 February 2019); House of Commons Home Affairs Committee EU Settlement Scheme Fifteenth Report of Session 2017-19, HC 1945, 30 May 2019, paras 6372; House of Commons Committee on the Future Relationship with the European Union, Implementing the Withdrawal Agreement: citizens' rights Second Report of Session 2019-21, HC 849, 20 October 2020, paras 77-85.

${ }^{26}$ Sajid Javid MP, Letter to Baroness Kennedy, 20 March 2019.

${ }^{27}$ Ibid.

${ }^{28}$ Ibid.

${ }^{29}$ See eg JUSTICE Preventing Digital Exclusion from Justice (2018); Age UK Later Life in a Digital World (2015); Citizens Advice Bureau Digital capability: understanding the digital needs of face-to-face clients of Citizens Advice (2016).

${ }^{30} \mathrm{We}$ focus on these groups because they are clearly protected under the Equality Act 2010 and the ECHR and, as we discuss below, there is clear evidence that digital-only status will tend to significantly disadvantage them. The same analysis might plausibly be extended to other groups, provided that they meet these conditions. Some groups might not meet the first condition (eg people who are deemed to be economically inactive), while other groups might not meet the second condition (eg men, women, or particular ethnic groups). See Office for National Statistics Exploring the UK's Digital Divide (4 March 


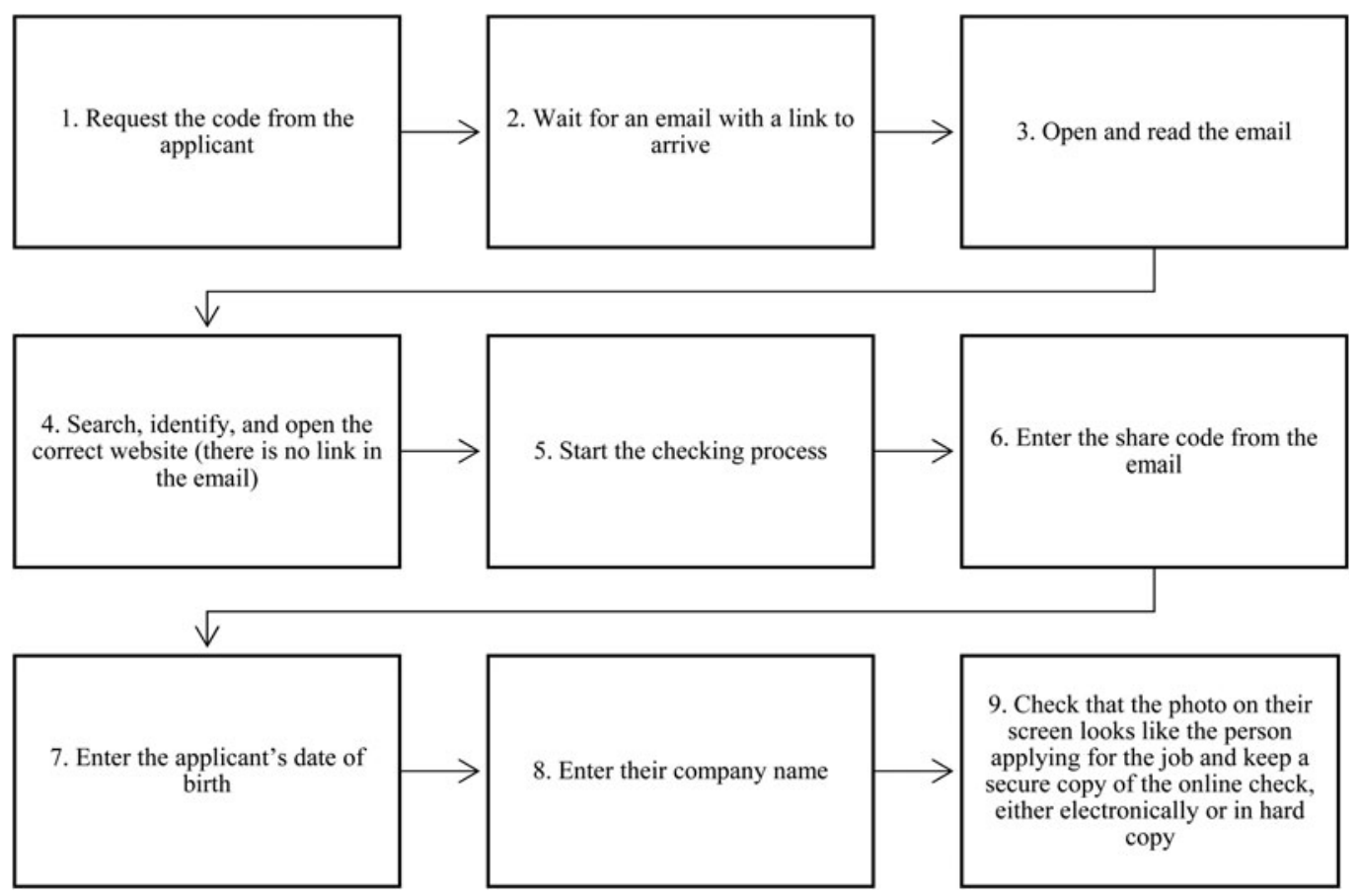

Figure 2. Steps required of an employer to established proof of status for a potential employee

available statistical evidence. Statistics are often used in indirect discrimination claims to establish that a provision, criterion or practice has a disparate impact on a particular group. ${ }^{31}$ In relation to disabled people, statistical evidence from the Office of National Statistics (ONS) and the Office for Communications (Ofcom) shows that they are less likely to have the hardware and digital literacy required to access and use digital status, as compared to the general public. Figure 3 summarises this statistical evidence ${ }^{32}$.

The statistical evidence available pertaining to older people is to similar effect. According to ONS and Ofcom, older people are less likely to have a household internet connection, ${ }^{33}$ to have access to or use a computer or tablet, ${ }^{34}$ to use a smartphone, ${ }^{35}$ or to use the internet, ${ }^{36}$ as compared to the general public. In general, as people become older, these disparities become larger. ${ }^{37}$

2019); G Blank et al 'OxIS 2019: digital divides in Britain are narrowing but deepening' (Oxford Internet Institute, 19 January 2020). We do not consider these broader questions here for reasons of space.

${ }^{31}$ See eg Essop v Home Office [2017] UKSC 27 at [28] (Lady Hale) (noting that, in indirect discrimination cases, 'it is commonplace for the disparate impact, or particular disadvantage, to be established on the basis of statistical evidence').

${ }^{32}$ Ofcom Access and Inclusion in 2018: Consumers' Experiences in Communications Markets (14 January 2019) p 13; Office for National Statistics Internet Users, UK: 2019 (24 May 2019).

${ }^{33}$ Office for National Statistics Internet Access - Households and Individuals, Great Britain: 2020 (7 August 2020). For example, $96 \%$ of all households in Great Britain have an internet connection, compared to $80 \%$ of households of 1 adult aged 65 and older.

${ }^{34}$ Ofcom Adults' Media Use and Attitudes Report 2020 - June 2020 (2020) p 3. For example, 66\% of all adults have access to a computer, compared to $61 \%$ of adults aged $65-74$ and $36 \%$ of adults aged 75 and older.

${ }^{35}$ Ibid, p 5 . For example, $81 \%$ of all adults use a smartphone, compared to $48 \%$ of adults aged $65-74$ and $30 \%$ of adults aged 75 and older.

${ }^{36}$ Office for National Statistics Internet Users, UK: 2019 (24 May 2019). For example, 90.8\% of all adults have used the internet in the last three months. This is larger than the equivalent figures for people aged between 65 and 74 (83.2\%) and aged 75 and older (46.8\%). $7.5 \%$ of all adults have never used the internet. This is smaller than the equivalent figures for people aged $65-74(13.5 \%)$ and aged 75 and older $(47.0 \%)$.

${ }^{37}$ See the sources cited at nn 33-36 above. 


\begin{tabular}{|c|c|c|c|}
\hline & & Non-disabled people & Disabled people \\
\hline \multirow[t]{2}{*}{$\begin{array}{l}\text { Household } \\
\text { ownership }\end{array}$} & $\begin{array}{c}\text { Computer } \\
\text { (PC/laptop/tablet) }\end{array}$ & $85 \%$ & $64 \%$ \\
\hline & Smartphone & $81 \%$ & $53 \%$ \\
\hline \multirow[t]{2}{*}{ Personal use } & $\begin{array}{c}\text { Computer } \\
\text { (PC/laptop/tablet })\end{array}$ & $77 \%$ & $54 \%$ \\
\hline & Smartphone & $75 \%$ & $45 \%$ \\
\hline \multirow[t]{2}{*}{ Internet use } & $\begin{array}{c}\text { In the last three } \\
\text { months }\end{array}$ & $94.8 \%$ & $78.3 \%$ \\
\hline & Never & $4.1 \%$ & $18.2 \%$ \\
\hline
\end{tabular}

Figure 3. Statistical evidence for the digital exclusion of disabled people

Regrettably, there is a lack of consistent data collection on Gypsy, Roma and Traveller people in general. $^{38}$ This means that evidence on their digital exclusion is limited. But the available evidence strongly suggests that these communities are seriously digitally excluded. Recent studies by grassroots organisations show that these groups are much less likely to have household internet connections, to have access to a computer, smartphone or tablet, to use the internet, or to feel confident performing tasks using digital technology, as compared to the general public. ${ }^{39}$ These communities are also seriously marginalised in ways which are independently correlated with digital exclusion (eg lack of access to education, low incomes, and low literacy levels). ${ }^{40}$

Digital exclusion, like other kinds of disadvantage, is intersectional. ${ }^{41}$ The overlap and interaction between a person's different characteristics can influence how and to what extent they experience digital exclusion. For example, Figure 4 shows how age, disability and socio-economic status intersect in relation to internet use in the $\mathrm{UK}^{42}$ It is important to keep this variation in mind when considering how digital-only status affects different people within particular groups, and whether the Government's mitigations might address some vectors of digital exclusion but not others.

To summarise this statistical evidence, and to illustrate how people in these groups will face difficulties with digital status in practice, we have constructed three composite profiles. ${ }^{43}$ The profiles are

\footnotetext{
${ }^{38}$ House of Commons Women and Equalities Committee Tackling Inequalities Faced by Gypsy, Roma and Traveller Communities Seventh Report of Session 2017-19, HC 360, 5 April 2019, para 48.

${ }^{39} \mathrm{~J}$ Scadding and S Sweeney 'Digital exclusion in gypsy and traveller communities in the United Kingdom' (Friends Families and Travellers, September 2018); M Bica et al 'P2B testing: the experience of Roma Support Group assisted applicants' (Roma Support Group, January 2019); Roma Support Group 'Statement on the impact of EU Settlement Scheme digital-only status on the Roma community in the UK' (October 2020). In London Borough of Enfield $v$ Persons Unknown [2020] EWHC 2717 (QB) at [21] (Nicklin J), the Court accepted the first of these studies as evidence of '[t]he level of digital exclusion in the gypsy and traveller community'.

${ }^{40}$ See Blank et al, above n 30; House of Commons Women and Equalities Committee, above n 38.

${ }^{41}$ See ML Fang et al 'Exploring privilege in the digital divide: implications for theory, policy, and practice' (2019) 59(1) The Gerontologist e1.

${ }^{42}$ Ofcom Access and Inclusion in 2018: Consumers' Experiences in Communications Markets (14 January 2019) p 14. 'Middle class' and 'Working class' are used as shorthand for National Readership Society social grades: ABC1 and C2DE, respectively.

${ }^{43}$ On this approach, see C Giannopoulou and N Gill 'Asylum procedures in Greece: the case of unaccompanied asylum seeking minors' in N Gill and A Good (eds) Asylum Determination in Europe: Ethnographic Perspectives (London:
} 


\begin{tabular}{|c|c|c|c|}
\hline \multicolumn{2}{|c|}{} & Non-disabled people & Disabled people \\
\hline \multirow{2}{*}{ Aged under 65 } & Middle class & $96 \%$ & $81 \%$ \\
\cline { 2 - 4 } & Working class & $93 \%$ & $67 \%$ \\
\hline \multirow{2}{*}{$\begin{array}{c}\text { Aged 65 years } \\
\text { and older }\end{array}$} & Middle class & $82 \%$ & $65 \%$ \\
\cline { 2 - 4 } & Working class & $53 \%$ & $35 \%$ \\
\hline
\end{tabular}

Figure 4. Internet use by age, disability and socioeconomic status

not intended to suggest that the people in these groups are homogenous. Rather, they are intended to encapsulate the statistical evidence on the comparative digital exclusion faced by these groups, and to highlight how digital-only status will disproportionately disadvantage these groups. We set out the three composite profiles below:

$\mathrm{P}$ is 28 years old. He has a visual impairment. He can read words printed on paper if the letters are not too small, but electronic screens appear blurred. As a consequence, $\mathrm{P}$ has never owned a computer. He has a landline phone and a basic mobile phone, but not a smartphone. He has never learned how to use the internet. With the assistance of his local Citizens Advice Bureau, P applied for and obtained settled status in July 2019.

B is 70 years old. She has never been particularly interested in modern technology. She feels like she manages perfectly well without it and she is a bit worried about the risk of being scammed. B has never bothered to get an internet connection at her flat. She does not own a computer, and she has a basic mobile phone for calling people in emergencies, but not a smartphone. She has barely used the internet in her life. B's niece helped her set up an email account some years ago, and a friend helped her to apply for and obtain settled status under the EUSS in February 2020, but she has not used the internet since then.

L is 39 years old. She is Roma. Her family does not have a household internet connection or own a computer. L has a smartphone, but she mainly uses it for phone calls and for basic social media every week or so. She does not otherwise use the internet and, in any case, the internet connection where she lives is often patchy. L generally does not like using technology to do things, as she finds she needs assistance to complete even simple tasks. With the assistance of a support group, L created an email address and obtained settled status in November 2019. She has not used her email address or accessed her status since then.

P, B and L face at least three obstacles to accessing and using their digital status. ${ }^{44}$ The first obstacle is a lack of access to internet infrastructure. While P and B could obtain an internet connection if they wished to, $\mathrm{L}$ struggles to get a reliable internet connection at all, because of where she lives. The second obstacle is a lack of access to the hardware required to access the internet. $\mathrm{P}$ and $\mathrm{B}$ own neither a computer nor a smartphone, and L does not own a computer. Another obstacle is a lack of digital literacy:

Palgrave Macmillan, 2019). The use of hypothetical claimant profiles was accepted by the Supreme Court in $R$ (UNISON) $v$ Lord Chancellor [2017] UKSC 51.

${ }^{44}$ J van Dijk The Network Society: Social Aspects of New Media (London: SAGE Publications, 1999), which distinguishes four kinds of access to technology: mental access, material access, skills access and usage access. 
the skills required to use digital technologies and the internet. ${ }^{45} \mathrm{P}, \mathrm{B}$ and $\mathrm{L}$ have low digital literacy. They have little to no experience of using the internet to perform the range of tasks required to maintain and use their digital status. As discussed above, those tasks include finding the correct website, navigating that website successfully, managing multiple media to identify and enter the correct information into the website (ie the ID document and the employer's email address), and completing a two-factor authentication process using a separate technology (ie a mobile phone or email address).

To demonstrate the impact of these obstacles in practice, it is useful to consider the following situations in which $\mathrm{P}, \mathrm{B}$ and $\mathrm{L}$ might need to use their digital status:

$\mathrm{P}$ has applied for a job. The employer calls $\mathrm{P}$ to arrange a time for an interview, and asks him to 'bring along documents for the right to work check'. P brings his passport and letter of confirmation of status to the interview, but the employer says that he needs a 'code' from him. P does not have a smartphone with which to access his status. The employer offers to let him use one of its computers, but this is no assistance. P cannot remember the ID document or email address associated with his EUSS application and he does not know how to find and navigate the website. P misses out on the job.

$B$ needs to find a new flat. She inspects one which she likes and she makes an offer to the real estate agent. The agent says that, before he gives B the flat, he has to check whether she is allowed to be in the UK. ${ }^{46}$ The agent asks her to go to a website and send him a link to check her status. B is confused. She remembers applying to the EUSS, but she doesn't understand what the landlord wants her to do. Several other people are interested in the flat, and the agent gives it to someone else before B can work out what to do.

L wants to apply to her local authority for council housing. The application form requires $\mathrm{L}$ to provide evidence of her immigration status, so that the authority can determine whether she is eligible. Although L has a smartphone, she does not know how to use it to show her status, and she also cannot remember the details for the email address she created when she applied to the EUSS. L includes her passport details in the application, but because she has not provided proof of her status, her application is rejected.

These examples illustrate how the Home Office's policy of providing digital-only proof of status puts $\mathrm{P}$, $\mathrm{B}$ and $\mathrm{L}$ at a particular disadvantage when compared to EU citizens who do not share their protected characteristics: disability, age, and race, respectively. ${ }^{47}$ The primary disadvantage is that $\mathrm{P}, \mathrm{B}$ and $\mathrm{L}$ cannot prove their status. P, B and L also suffer secondary disadvantages because of their inability to prove their status: exposure to potential lost benefits (eg medical treatment or housing) or additional burdens (eg upfront charges or administrative removal) and the distress caused by that exposure. EU citizens without $\mathrm{P}, \mathrm{B}$, and L's protected characteristics are more likely to be able to prove their status, because they are, statistically speaking, more likely to have access to internet infrastructure and the necessary hardware, and to have the requisite digital literacy. Consequently, they are less likely to be exposed to the disadvantages suffered by $\mathrm{P}, \mathrm{B}$ and $\mathrm{L}$.

$\mathrm{P}, \mathrm{B}$ and L are composite profiles. Some people who share their protected characteristics will have no trouble accessing and using their status. And some people without their protected characteristics will, for whatever reason, suffer the same disadvantages. But this does not undermine our claim that digital-only status is indirectly discriminatory. As Lady Hale noted in Essop v Home Office,

\footnotetext{
${ }^{45}$ These skills range from simply turning on a device and connecting to the internet to engaging with people and services online. See eg Department for Education 'National standards for essential digital skills' (23 April 2019).

${ }^{46} \mathrm{C}$ Patel and C Peel 'Passport please: the impact of the right to rent checks on migrants and ethnic minorities in England' (Joint Council for the Welfare of Immigrants, February 2017).

${ }^{47}$ Equality Act 2010, ss 4, 5, 6, 9, 19; Glor v Switzerland App no 13444/04 (ECtHR, 30 April 2009); Schwizgebel v Switzerland App no 25762/07 (ECtHR, 10 June 2010); DH v Czech Republic (2008) 47 EHRR 3.
} 
'there is no requirement that the [policy] put every member of the group sharing the particular protected characteristic at a disadvantage' compared to every person without that characteristic. ${ }^{48}$ What is required is that the proportion of disabled people, older people or people from Gypsy, Roma and Traveller communities who cannot prove their status is larger than the proportion of people without those characteristics. ${ }^{49}$ This is established by the statistical evidence. Once that evidence is accepted, it 'inevitably follows' that digital-only status gives rise to indirect discrimination. ${ }^{50}$

Our analysis, articulated through the use of composite profiles, is consistent with the Government's own analysis of similar digital status systems. In March 2018, the Government Digital Service (GDS) assessed the Home Office's 'Prove your right to work' service - an online system for people to prove their right to work in the UK. GDS noted that the Home Office had 'very strong evidence' that any move from physical proof of status to 'digital only services' would 'cause low digital users a lot of issues. ${ }^{51}$ It concluded that there was 'a clearly identified user need for the physical card at present, and without strong evidence that this need can be mitigated for vulnerable, low-digital skill users, it should be retained'. ${ }^{52}$ This conclusion applies with equal force to the use of digital-only status in the EUSS.

Our analysis is also supported by the important decision in LH Bishop Electrical Co Ltd $v$ HM Revenue and Customs, a successful challenge to digital discrimination in another area of public administration. ${ }^{53}$ In 2010, HM Revenue and Customs (HMRC) made regulations requiring businesses to file their value added tax returns online, subject to limited exemptions. ${ }^{54}$ In Bishop Electrical, the First-tier Tribunal (Tax Chamber) found that the regulations indirectly discriminated against people on the basis of age, disability and remote location, and thus violated Article 14 of the European Convention on Human Rights (ECHR). ${ }^{55}$ The Tribunal accepted statistical evidence that older people, disabled people and those living remotely - like the appellants before it - were less likely to own or know how to use a computer, or to have access to the internet. ${ }^{56}$ It was therefore more difficult for these groups to comply with the obligation to file returns online. ${ }^{57}$ And, as we discuss further below, the Tribunal rejected HMRC's ostensible justifications for this discrimination. ${ }^{58}$ In response to the decision, HMRC amended the regulations to enable people to make a paper or telephone return if an electronic return was not 'reasonably practicable'. 59

Where a public authority's apparently neutral policy disadvantages a protected group, as we argue is the case with digital-only status, there are two avenues through which it can still be considered lawful. ${ }^{60}$ The public authority can take steps to eliminate the disadvantage suffered by the protected group, by adjusting the policy or providing additional assistance to members of the group. Or the public authority can show how, notwithstanding that disadvantage, the policy is justified, because it is a proportionate means of achieving a legitimate aim. The next two parts of this paper show that, in the case of digital-only status, these approaches have been unsuccessful to this point. The Home Office has neither eliminated nor adequately justified the indirectly discriminatory effects of the policy.

\footnotetext{
${ }^{48}$ Essop v Home Office [2017] UKSC 27 at [27].

${ }^{49}$ Ibid, at [27] (Lady Hale).

${ }^{50} R(H)$ v Ealing London Borough Council [2017] EWCA Civ 1127 at [58] (Sir Terence Etherton MR).

${ }^{51}$ Government Digital Service 'Prove your right to work - beta' (Service Standard Reports, 2 March 2018).

${ }^{52}$ Ibid.

${ }^{53}$ [2013] UKFTT 522 (TC).

${ }^{54}$ The regulations exempted practising members of religious groups 'whose beliefs are incompatible with the use of electronic communications', and companies which were insolvent: Bishop Electrical [2013] UKFTT 522 (TC) at [21].

${ }^{55} \mathrm{Ibid}$, at [803]-[811].

${ }^{56}$ Ibid, at [369]-[372], [384]-[403], [713].

${ }^{57}$ Ibid, at $[714]-[726]$.

${ }^{58}$ Ibid, at [760]-[789].

${ }^{59}$ Value Added Tax (Amendment) (No 2) Regulations 2014, SI 2014/1458.

${ }^{60} R$ (Ward) v London Borough of Hillingdon [2019] EWCA Civ 692 at [75] (Lewison LJ).
} 


\section{Has the discrimination been eliminated?}

In the context of the EUSS, the Home Office has acknowledged that digital-only status may disadvantage people 'who may find it harder to use digital services because they are not regular internet users. ${ }^{61}$ However, it argues that it has taken steps to limit the impact of this disadvantage. ${ }^{62}$ Before we show why the steps taken are an unconvincing response to the discriminatory impacts, two important points must be made about this analysis. First, to refute a claim of indirect discrimination, a defendant's mitigations must 'eliminate' the disadvantage suffered by the protected group. ${ }^{63}$ As Lewison LJ noted in $R$ (Ward) $v$ London Borough of Hillingdon:

[T] he key principle is that the goal is equality of outcome. If a [policy] results in a relative disadvantage as regards one protected group, any measure relied on as a "safety valve" must overcome that relative disadvantage. Put simply, if the scales are tilted in one direction, adding an equal weight to each side of the scales does not eliminate the tilt. ${ }^{64}$

It is not sufficient that any measures merely go some way to alleviating that disadvantage. ${ }^{65}$ Secondly, the public authority bears the burden of proof in this regard. It must adduce evidence establishing that its mitigations have actually eliminated the disadvantage to the protected group. ${ }^{66}$ If that evidence is absent, equivocal or unconvincing, the defendant's mitigations will be assumed not to have addressed the disadvantage.

The Home Office claims to have taken four steps to eliminate the disadvantage caused by digital-only status in the context of the EUSS. First, it has allowed EU citizens to continue to use their passport or national ID card to prove their immigration status until 30 June $2021 .^{67}$ This is said to give EU citizens 'time to get used to transitioning from using physical documents to accessing and sharing their immigration status information online'. ${ }^{68}$ But this six-month 'grace period' after the end of the transition period does nothing to address the disadvantages discussed above. ${ }^{69}$ It is not realistic to suggest that, within a matter of months, individuals in circumstances akin to $\mathrm{P}, \mathrm{B}$ and $\mathrm{L}$ will be able to acquire the requisite hardware, skills, and confidence to access and use their digital status.

Secondly, the Home Office claims that it already provides successful EUSS applicants with physical notice of their leave to remain in the UK. During a House of Lords debate on digital-only status, Baroness Williams of Trafford, Minister of State for the Home Department, put this point in the following terms:

I would like to reassure noble Lords that we already provide people who are granted settled or pre-settled status with a formal written notification of their leave. It is sent in the form of a letter, by post, or a PDF, by email, and sets out their immigration status in the UK. They can retain the letter, or print it, or electronically store the PDF and keep it as confirmation of their status for their own records and use it if they wish when contacting the Home Office about their status. ${ }^{70}$

Baroness Williams asserted that these confirmation letters 'should reassure individuals about their status when dealing with the Home Office in the future..$^{71}$ But a confirmation letter is not and cannot be accepted as proof of immigration status. ${ }^{72}$ As Lord Paddick noted in the same debate:

\footnotetext{
${ }^{61}$ Home Office Policy equality statement: EU Settlement Scheme (December 2020) para 307.

${ }^{62}$ Ibid, paras 310-315.

${ }^{63} R$ (Ward) $v$ London Borough of Hillingdon [2019] EWCA Civ 692 at [87] (Lewison LJ).

${ }^{64} \mathrm{Ibid}$, at [86]. See also OA $v$ Secretary of State for Education [2020] EWHC 276 (Admin) at [49] (Nicol J).

${ }^{65}$ Such a mitigation may make the disadvantage easier to justify, which we consider further below.

${ }^{66} R$ (Ward) $v$ London Borough of Hillingdon [2019] EWCA Civ 692 at [87] (Lewison LJ).

${ }^{67}$ Home Office, above n 61, para 314.

${ }^{68}$ Hansard HL Deb, vol 806, cols 467-73, 5 October 2020.

${ }^{69}$ Explanatory Notes to the Immigration and Social Security Coordination (EU Withdrawal) Bill 2020, para 10; Withdrawal Agreement, above n 13, Art 18(1)(b), (2).

${ }^{70}$ Hansard HL Deb, vol 805, col 1094, 14 September 2020.

${ }^{71}$ Ibid.

${ }^{72}$ Baroness Williams accepted this very point in the course of her remarks: ibid.
} 
The Government have said, time and again, that, as proof of the recipient's immigration status, these letters are not worth the paper they are printed on. It is disingenuous of the Minister to pray in aid these letters in answer to these amendments [providing for the issue of physical proof of status under the EUSS]. ${ }^{73}$

In short, the issuing of unofficial confirmation letters goes no meaningful distance to address the disadvantages caused by digital-only proof of residence.

Thirdly, the Home Office has designed the webpage for accessing and proving status in accordance with government accessibility requirements. ${ }^{74}$ The Home Office's accessibility statement for the webpage notes that it wants 'as many people as possible to be able to use this website. ${ }^{75}$ To achieve this, the web design has incorporated certain features, including that that users can: change colours, contrast levels, and fonts; zoom in up to $300 \%$ without the text spilling off the screen; navigate most of the service using just a keyboard; navigate most of the service using speech recognition software; and listen to most of the service using a screen reader. Inclusive design of digital public services is essential to their success. It plays a vital role in addressing the difficulties which those services present for people who are digitally excluded, and any efforts in this regard ought to be welcomed. But inclusive design 'may nonetheless be insufficient to address some of the more complex issues of digital divide. ${ }^{76}$ The circumstances of $\mathrm{P}, \mathrm{B}$ and $\mathrm{L}$ demonstrate this point. The inclusive design of the relevant webpage does not address the essential problem with digital-only status in their circumstances: lack of the resources and skills necessary to access the webpage in the first place.

Finally, the Home Office argues that it has created or funded services to support people in accessing and proving their status. ${ }^{77}$ It has established the Settlement Resolution Centre to assist people who are applying to the EUSS or accessing their status. ${ }^{78}$ It has also funded 72 community organisations across the UK to support vulnerable people in applying to the EUSS. ${ }^{79}$ Finally, it has engaged 'We Are Digital', a private digital training provider, to provide an 'Assisted Digital' service for EUSS applicants. ${ }^{80}$ There are, however, multiple problems with seeking reassurance in these measures.

The first problem is that it is unclear whether and for how long these services will actually be available for people struggling to access their status. At present, the Home Office has only funded the 72 community organisations to help people apply to the EUSS, and not to help people access and prove their status into the future. ${ }^{81}$ Their current funding expires at the end of September $2021 .^{82}$ The same appears to be true of the Assisted Digital services provided. ${ }^{83}$ This would leave the Settlement Resolution Centre as the only support for people disadvantaged by digital-only status after the end of the 'grace period' on 30 June 2021, if it remains open.

The second problem is that these support services may be inaccessible to the very people who are disadvantaged by digital-only status. For example, the Settlement Resolution Centre can be contacted

\footnotetext{
${ }^{73}$ Ibid.

${ }^{74}$ Home Office, above n 61, para 310.

${ }^{75}$ Home Office 'Accessibility Statement' (18 September 2020), available at https://apply-to-visit-or-stay-in-the-uk.homeoff ice.gov.uk/accessibility-statement.

${ }^{76}$ S Ranchordás 'Connected but still excluded? Digital exclusion beyond internet access' in M Ienca et al (eds) The Cambridge Handbook of Life Sciences, Information Technology and Human Rights (Cambridge: Cambridge University Press, 2021).

${ }^{77}$ Home Office, above n 61, paras 310, 314-315.

${ }^{78}$ Home Office 'EU Settlement Scheme (settled and pre-settled status) or Service Provider from Switzerland visa applications', available at www.gov.uk/contact-ukvi-inside-outside-uk/y/inside-the-uk/eu-settlement-scheme-settled-and-pre-settled-status-orservice-provider-from-switzerland-visa-applications.

${ }^{79}$ Home Office 'Get help applying to the EU Settlement Scheme', available at www.gov.uk/help-eu-settlement-scheme.

${ }^{80}$ Home Office 'Get help with your online Home Office application', available at www.gov.uk/assisted-digital-help-onlineapplications.

${ }^{81}$ See eg Home Office 'EU Settlement Scheme: community support for vulnerable citizens' (8 December 2020).

${ }^{82}$ Hansard HC Deb, vol 697, col 160WH, 16 June 2021.

${ }^{83}$ See eg Home Office, above n 81 .
} 
via telephone or an online form. ${ }^{84}$ The telephone number is listed on a government webpage, but it is unclear how people who are digitally excluded are to find this information. ${ }^{85}$ The online form is, by definition, inaccessible to such people. ${ }^{86}$ Another potential barrier is cost. Calls to the Settlement Resolution Centre cost up to 10p per minute from landlines and up to 40p per minute from mobile phones. ${ }^{87}$ After inspecting the Government's arrangements for the applications to the EUSS, the Independent Chief Inspector for Borders and Immigration noted that these charges 'could act as a deterrent to those most in need of help to apply. ${ }^{88}$ This concern applies with even greater force in relation to people accessing and proving their status. In the hostile environment, such people will repeatedly be required to prove their status, and thus will repeatedly have to incur the cost of contacting the Settlement Resolution Centre for assistance.

The third problem is that these support services may be unable to meaningfully assist people who are digitally excluded. Consider B, the 70-year-old woman in the process of finding a new flat. Even if $B$ managed to find out about the Settlement Resolution Centre, locate its phone number, and speak to a member of staff (when they are available), she would still face significant hurdles in proving her status. The official would need to ask B to find and travel to a publicly accessible computer (eg in a public library), because B does not have a computer or smartphone. The official would then need to guide $\mathrm{B}$ through the process of proving her status, notwithstanding that $\mathrm{B}$ has barely used a computer or the internet in her life. This process would also have to be completed very quickly. In a competitive rental market, properties are often let the same day they are advertised, so any delay would risk B losing the flat. ${ }^{89}$ And this process would have to be completed every time B had to prove her status in the hostile environment: opening a bank account, renting a property, accessing healthcare, and so on. It is not credible to claim that these support services eliminate the disadvantages caused by digital-only status.

The Home Office has said that it is exploring additional steps to address some of the deficiencies we have identified. ${ }^{90}$ For example, the Home Office is 'developing' automated, system-to-system checks with other departments and the NHS, so that EU citizens will be able to access public services without personally having to prove their status. ${ }^{91}$ These automated checks are yet to materialise and, even once they are in place, they would not assist people with proving their status to private parties, such as employers, landlords, and banks. In her review of the Windrush scandal, Wendy Williams concluded that the Home Office had been 'overly optimistic' about 'the effectiveness of the proposed "mitigations"' for its hostile environment policy. ${ }^{92}$ Recent history appears to be repeating itself in this respect too. At the very least, the Home Office is yet to present a shred of convincing evidence that the steps it has taken go close to eliminating the disadvantages caused by digital-only status.

\footnotetext{
${ }^{84}$ Home Office, above $\mathrm{n} 78$.

${ }^{85} \mathrm{~A}$ similar problem arises in respect of the grant-funded community organisations. One webpage sets out a full list of those organisations and their contact details, while another asks people to enter their postcode and identifies the nearest organisation that can help them. See Home Office, above n 79 ; Home Office 'List of organisations' (8 December 2020), available at www.gov.uk/government/publications/eu-settlement-scheme-community-support-for-vulnerable-citizens/list-oforganisations.

${ }^{86}$ Home Office 'Ask a question about applying for settled status', available at https://eu-settled-status-enquiries.service.gov. uk/start.

${ }^{87}$ House of Commons Home Affairs Committee, above n 25, para 18.

${ }^{88}$ Independent Chief Inspector of Borders and Immigration An inspection of the EU Settlement Scheme: An inspection of the EU Settlement Scheme: April 2019 to August 2019 (February 2020) para 6.22.

${ }^{89}$ Independent Chief Inspector of Borders and Immigration An Inspection of the 'Right to Rent' Scheme (March 2018) paras $3.12,6.18$, noting that landlords complained about the 48-hour response time for the Home Office's service for checking the immigration status of potential tenants, because they needed 'a more immediate response'.

${ }^{90}$ Home Office, above n 61, para 310 ('we are exploring additional support options for those using our online services').

${ }^{91}$ Hansard HL Deb, vol 805, col 1094, 14 September 2020; Hansard HL Deb, vol 806, col 467, 5 October 2020.

${ }^{92}$ Williams, above n 3, p 86.
} 


\section{Unconvincing justifications}

This part of the paper turns to address the question of whether digital-only status, as operated within the EUSS, can still be justified as a proportionate means of pursuing a legitimate aim. The central questions on the issue of proportionality are those set out by Lord Reed in Bank Mellat:

(1) whether the objective of the measure is sufficiently important to justify the limitation of a protected right, (2) whether the measure is rationally connected to the objective, (3) whether a less intrusive measure could have been used without unacceptably compromising the achievement of the objective, and (4) whether, balancing the severity of the measure's effects on the rights of the persons to whom it applies against the importance of the objective, to the extent that the measure will contribute to its achievement, the former outweighs the latter ... In essence, the question at step four is whether the impact of the rights infringement is disproportionate to the likely benefit of the impugned measure. ${ }^{93}$

We argue that digital-only status is not a proportionate means of achieving any of the Home Office's apparent objectives. First, we examine the range of objectives behind the policy, showing that they rest on problematic assumptions. ${ }^{94}$ Secondly, we propose less intrusive measures that would not unacceptably compromise the achievement of the policy's objectives. Finally, we argue that the Home Office has failed to strike a fair balance between those policy objectives and the rights of people disadvantaged by digital-only status in the ways discussed above.

\section{(a) The objectives of digital-only status}

There are three primary objectives behind the digital-only status policy: increasing convenience for holders of status and third parties, reducing costs for the Government, and enhancing the security of immigration status. ${ }^{95}$ Similar objectives have been advanced to justify the discriminatory or perverse effects of digital systems in other areas of government. ${ }^{96}$ Before examining these objectives in detail, however, it is important to note that they all connect to a more general, underlying objective: enforcing immigration and border controls. The promise of digital-only status is that it will enable the UK to control its borders and manage immigration more conveniently, more cheaply and more securely. Expressed at that level of generality, this is a legitimate aim for the Government to pursue. However, it cannot be said to be proportionate to implement a policy in the pursuit of enforcing immigration law and policy that has the effect of disconnecting people from their proof of lawful residence. In this way, digital-only status undermines the very aim which is said to justify it. The courts have also recognised that there is no rational connection between the state's interest in immigration control and discriminatory treatment of various groups with protected characteristics. ${ }^{97}$

The first objective of digital-only status is to increase convenience for holders of status and the third parties required to check status. Holders of status 'will be able to view, understand and update their information from a single place', and 'will not have to resubmit information or prove things again in subsequent applications where there has been no change. ${ }^{98}$ In this way, digital-only status allows the Home Office to generate 'customer intimacy' by offering a more personalised service that is easier

\footnotetext{
${ }^{93}$ Bank Mellat $v$ HM Treasury (No 2) [2013] UKSC 39 at [74]. This was recently confirmed as the appropriate test in $R$ (Ward) v Hillingdon London Borough Council [2019] EWCA Civ 692 at [91] (Lewison LJ), a case brought under the Equality Act 2010, and Secretary of State for the Home Department $v$ R (Joint Council for the Welfare of Immigrants) [2020] EWCA Civ 542 at [112]-[151] (Hickinbottom LJ), a case concerning immigration policy brought under the ECHR.

${ }^{94}$ The Government has not yet published an overarching statement of justifications for the policy. As a result, we have relied on a range of government statements and official documents to understand the rationale for the policy.

${ }^{95}$ These are the three primary objectives, though the Government has also advanced other ancillary justifications: see Welsh and Tomlinson, above $\mathrm{n} 8$.

${ }^{96}$ See eg Secretary of State for Work and Pensions $v$ Johnson [2020] EWCA Civ 778; $R$ (The Motherhood Plan) v HM Treasury [2021] EWHC 309 (Admin).

${ }^{97} R(D M A) v$ Secretary of State for the Home Department [2020] EWHC 3416 (Admin) [284] (Knowles J).

${ }^{98} \mathrm{HM}$ Government, above n 5, p 72.
} 
to access and use. ${ }^{99}$ It is also intended to reduce errors in proving status by reducing 'piecemeal interactions, services and paper products' which should make it 'easier for users to transact with... services in a streamlined, seamless way'. ${ }^{100}$ From the perspective of third parties, they should 'see only the information that is relevant and proportionate to their need'. ${ }^{101}$ This should 'remov[e] the need for employers, and others, to authenticate the myriad different physical documents and interpret complex legal terminology or confusing abbreviations. ${ }^{102}$ The outcome of the switch to digital status, on this reasoning, should be that it is more convenient for all involved to share and check status. ${ }^{103}$

It is clearly legitimate for the Government to make proving immigration status more convenient. But it is essential to examine whether digital-only status will actually achieve this objective, and which people will enjoy these benefits in practice. Putting to one side the problems of digital exclusion discussed above, it is not obvious that digital immigration checks will generally be more convenient for status-holders and third parties. There is already evidence that third parties are unwilling to undertake the checks required under the hostile environment. In January 2020, the Court of Appeal found that the right to rent scheme caused indirect discrimination, although the discrimination was justified as a proportionate means of deterring irregular immigration. ${ }^{104}$ The Court accepted evidence that landlords were less likely to rent to those without British passports, those with complicated immigration status, and people with 'foreign accents or names' as a result of the scheme, due to administrative convenience and a fear of the consequences of letting to an irregular immigrant. Quite simply, landlords felt they were 'forced to discriminate against certain groups, rather than face the possibility of a fine'. ${ }^{105}$ The research underpinning the case, conducted by the Joint Council for the Welfare of Immigrants (JCWI), also found that the majority (65\%) of landlords would not rent to someone who needed time to provide documentation, an 'attitude which will affect anyone applying for a tenancy who lacks clear documents or does not have documents, such as a passport, to hand'. ${ }^{106}$ When landlords were presented with a potential tenant who required the use of an 'online checking tool' (which requires landlords to request information about a tenant's immigration status from the Home Office and takes 48 hours to receive a response), $85 \%$ of them did not respond. Only $3.3 \%$ of the landlords contacted by this tenant responded and invited further interaction. ${ }^{107}$

The online checking procedure for digital status, described above, can be time-consuming, particularly for those unfamiliar with it. The reluctance of landlords captured in the JCWI research may be exacerbated by a lack of physical proof of status or if they find it 'too complicated or troublesome to engage with electronic systems'. ${ }^{108}$ Similar concerns have been raised about employers and the prospect that they may choose to hire or retain someone with more familiar status documents. Ultimately, as the Home Affairs Committee observed:

[T] his system risks being confusing, increases the workload on employers and landlords, relies on their goodwill and engagement with this new and unfamiliar process, requires individuals and employers to have the necessary electronic hardware, and could result in individuals not employing or renting to someone due to the confusion and difficulties involved in proving status. ${ }^{109}$

\footnotetext{
${ }^{99}$ Ibid.

${ }^{100}$ Ibid, p 72.

${ }^{101}$ Ibid, p 73 .

${ }^{102}$ Hansard HL Deb, vol 806, col 469, 5 October 2020.

${ }^{103} \mathrm{HM}$ Government, above n 5, p 72.

${ }^{104}$ Secretary of State for the Home Department $v$ R (Joint Council for the Welfare of Immigrants) [2020] EWCA Civ 542 at [146]. This decision overturned the High Court's finding that the scheme was unlawful: $R$ (Joint Council for the Welfare of Immigrants) $v$ Secretary of State for the Home Department [2019] EWHC 452 (Admin).

${ }^{105}$ S Grant and C Peel "No passport equals no home": an independent evaluation of the "right to rent" scheme' (JCWI, 3 September 2015) p 57.

${ }^{106}$ Ibid.

${ }^{107}$ Ibid, p 47.

${ }^{108}$ EU Justice Sub-Committee, Letter to Sajid Javid MP (27 February 2019).

${ }^{109}$ House of Commons Home Affairs Committee, above n 25, para 65.
} 
Far from being convenient for holders of status, digital-only status could lead to difficulty, and even discrimination, when seeking to access homes, jobs, and services. The Exiting the EU Committee observed the potential further risk of exploitation if someone 'cannot persuade an employer or landlord of their status' ${ }^{110}$ As discussed above, it is also questionable whether a short transition window where paper documents can still be used - as adopted in the context of EUSS - eliminates these risks. ${ }^{111}$ These doubts about the supposed benefits of digital status seem to be reflected in the attitudes of EU citizens in general. In January 2020, a survey of over 3,000 EU citizens found that $89 \%$ were unhappy with the lack of physical proof of status under the EUSS. ${ }^{12}$

The convenience of digital-only status also rests heavily on the performance of the underlying technology. There have already been many reported technical errors, including where an individual trying to access the right-to-work scheme faced the error message stating 'we can't show your record'. ${ }^{113}$ Technical errors would leave people 'in limbo, unable to assert their rights'. ${ }^{114}$ Other digital errors could also erode trust in the system. For instance, there have already been a significant number of data breaches in the EUSS. ${ }^{115}$

Finally, it is important to note, as we did above, that various holders of status will not enjoy the convenience of digital-only status. For people who are digitally excluded, digital-only status not only offers no convenience, but risks disconnecting them from proof of their lawful entitlement to reside in the UK. As we discuss further below, the benefits and burdens under the digital-only status policy are unfairly distributed. Even accepting the importance of the objective of improving convenience, it cannot justify a blanket policy which risks disconnecting lawful residents from proof of their status.

The second objective of digital-only status is to reduce costs for the Government. ${ }^{116}$ For the Government, a digital-only system will be significantly cheaper than a paper-based system. Since 2008, the Home Office has issued one million residence cards. ${ }^{117}$ A paper-based system for the EUSS would require over four million additional residence cards for applicants, plus additional cards for replacements and changes of status. The Government has estimated that issuing these

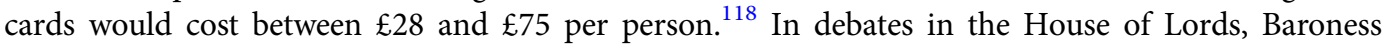
Williams argued that a paper-based system for the EUSS 'would incur a significant and unfunded cost' and 'divert investment away from developing the digital services and support for migrants using those services that we need for the future. ${ }^{119}$ Under the Withdrawal Agreement, the UK could charge EU citizens for at least some of this cost, but only up to the amount that it charges UK nationals for issuing similar documents. ${ }^{120}$

There are several problems with the cost objective. First, as a matter of law, there is some doubt over whether cost savings can justify indirect discrimination. As Lord Hope and Lady Hale said in O'Brien $v$ Ministry of Justice:

\footnotetext{
${ }^{110}$ House of Commons Exiting the European Union Committee, above n 25, para 48.

${ }^{111}$ Ibid, para 48 .

${ }^{112} \mathrm{~T}$ Bueltmann 'Experiences and impact of the EU Settlement Scheme: report on the3million settled status survey' (The3Million, January 2020) p 26.

${ }^{113}$ The3Million 'Provide EU citizens with a physical document as proof of (pre-)settled status' (The3Million, September 2019) p 1.

${ }^{114}$ House of Commons Home Affairs Committee, above n 25, para 65.

${ }^{115}$ Independent Chief Inspector of Borders and Immigration, above n 88, para 6.94 .

${ }^{116}$ House of Commons Home Affairs Committee, above n 25, para 67 ('The Home Office has said the digital code system will be less resource intensive').

${ }^{117}$ Secretary of State for the Home Department $v$ R (Joint Council for the Welfare of Immigrants) [2020] EWCA Civ 542 at [17] (Hickinbottom LJ).

${ }^{118}$ These figures are based on various estimates given by Baroness Williams to the House of Lords on 5 October and 21 October 2020. See Hansard HL Deb, vol 806, col 472, 5 October 2020; Hansard HL Deb, vol 806, col 1604, 21 October 2020.

${ }^{119}$ Hansard HL Deb, vol 806, col 472, 5 October 2020.

${ }^{120}$ Withdrawal Agreement, above n 13, Art 18(1)(g).
} 
Of course there is not a bottomless fund of public money available. Of course we are currently living in very difficult times. But the fundamental principles of equal treatment cannot depend upon how much money happens to be available in the public coffers at any one particular time or upon how the State chooses to allocate the funds available between the various responsibilities it undertakes. ${ }^{121}$

Some lower court and tribunal decisions draw a distinction between the goal of cost savings alone, which cannot justify discriminatory effects, and cost savings as one among several goals, which together can justify such effects. ${ }^{122}$ Other decisions draw another distinction between governments, which cannot use cost savings as a justification at all, and employers, which can use cost savings as one among several justifications. ${ }^{123}$ These distinctions are not without difficulty. ${ }^{124}$ Whatever the precise position, the authorities suggest that the courts are slow to accept cost savings as justifying a discriminatory government policy.

Secondly, digital-only status does not reduce costs so much as shift them. It places the burden on status holders and third parties to be in a position to use digital status: to have access to the requisite internet infrastructure and hardware, and to have the requisite digital literacy. Many people will have to incur substantial costs to do so. A similar issue arose in Bishop Electrical. The purpose of making online tax filing mandatory was 'to save HMRC costs in collecting taxes': about $£ 32$ per person per year. ${ }^{125}$ But the policy would compel people who did not own or know how to use a computer to spend up to $£ 400$ per year to be in a position to file their returns online. ${ }^{126}$ The First-tier Tribunal found that these additional costs 'would be out of all proportion to the cost benefit to HMRC. ${ }^{127}$ This disproportionate cost-shifting, in combination with several other factors, meant that HMRC's cost savings did not justify the discriminatory effects of mandatory online filing. ${ }^{128}$

A similar argument could be made about digital-only status in the context of the EUSS. The Government says that a digital-only system will save it a one-off cost of $£ 28$ and $£ 75$ per person, together with some additional costs for replacements and changes of status. ${ }^{129}$ But people who are digitally excluded may have to incur larger and ongoing costs to use digital status. In 2020, the Joseph Rowntree Foundation and Loughborough University estimated that, to reach a minimum acceptable standard of living, an adult in the UK would need to spend about $\mathfrak{E 3 8 0}$ per year on digital technologies and the internet. ${ }^{130}$ In other words, from the perspective of a person who is digitally excluded, digital-only status may impose costs which are disproportionate to the expected savings for the Government. For these reasons, we suggest that the cost objective provides, at best, a weak justification for digital-only status.

\footnotetext{
${ }^{121}$ O'Brien $v$ Ministry of Justice [2013] UKSC 6 at [74]. See also $R$ (Coll) $v$ Secretary of State for Justice [2017] UKSC 40 at [40] (Lady Hale) $c f . R$ (The Motherhood Plan) v HM Treasury [2021] EWHC 309 (Admin) at [83]-[84] (Whipple J).

${ }^{122}$ For a recent review of the authorities, see Heskett $v$ Secretary of State for Justice [2020] EWCA Civ 1487 at [45]-[106] (Underhill LJ).

${ }^{123}$ See eg Cross v British Airways plc [2005] IRLR 423 at [72] (Burton P).

${ }^{124}$ O'Brien v Ministry of Justice [2013] UKSC 6 at [63] (Lord Hope and Lady Hale); Woodcock v Cumbria Primary Care Trust [2011] ICR 143 at [32] (Underhill P).

${ }^{125}$ Bishop Electrical [2013] UKFTT 522 (TC) at [375], [587].

${ }^{126}$ Ibid, at [378].

${ }^{127}$ Ibid, at [793].

${ }^{128}$ Ibid, at [779]-[780], [793]-[794].

${ }^{129}$ These figures are based on various estimates given by Baroness Williams to the House of Lords on 5 October and 21 October 2020. See Hansard HL Deb, vol 806, col 472, 5 October 2020; Hansard HL Deb, vol 806, col 1604, 21 October 2020.

${ }^{130}$ Loughborough University 'Latest MIS results', available at https://www.lboro.ac.uk/research/crsp/mis/results/. This figure includes amounts for a smartphone, a phone contract including mobile data, a home broadband internet connection, and a laptop. It forms part of the Minimum Income Standard, an estimate of the level of income required for a minimum acceptable standard of living in the UK. The Joseph Rowntree Foundation and Loughborough University have published and updated the Minimum Income Standard regularly since 2008. See A Davis et al 'A minimum income standard for the United Kingdom in 2020' (Joseph Rowntree Foundation, July 2020). In R (UNISON) v Lord Chancellor [2017] UKSC 51, the Supreme Court relied on the Minimum Income Standard when analysing whether tribunal fees were affordable for low- and middle-income households.
} 
The third objective of digital-only status is to improve the security of immigration status. Physical documents, so the reasoning goes, are at risk of being lost, stolen or damaged, and digital status, suspended in the cloud, is insulated from such earthly risks. ${ }^{131}$ There is a basis for these security concerns. For example, there have been cases where paper documents have been controlled by others, including in cases of domestic violence, modern slavery, and human trafficking. ${ }^{132}$ In such circumstances, it is possible to imagine digital status giving status-holders firmer possession of their proof of residence. Similarly, it is plausible that the enhanced security of the digital code system may reduce the possibility of forgery and fraud. ${ }^{133}$ That being said, the evidence for these claims is limited.

On the other hand, there is emerging evidence that digital status generates new security risks. For instance, there have been reports of 'advice sharks' making applications on behalf of others, charging for this service (when the application is free), and then retaining access through email addresses and phone numbers to charge individuals further for access to their status. ${ }^{134}$ The EU Justice Sub-Committee also raised concerns that digital-only proof could be used by people traffickers and illegal gangmasters to exert control over their victims. ${ }^{135}$ Digital status may be more secure for some people, but it remains vulnerable to the same problems as physical status and potentially opens up new routes for exploitation. For example, if a perpetrator was in control of a person's initial application (and therefore the phone number and email address associated with it, to which the security code is sent), they would have control over who could access the person's status.

The security objective may also be undermined by less sinister but equally problematic practical issues. For instance, evidence suggests that some applicants lack an email address to receive their status. This has resulted in advisors 'setting up email addresses for people and maintaining a record of log-in details in-house as a backup for individuals'. ${ }^{136}$ Such a fix - which may seem an appropriate immediate solution - ultimately leaves a person disconnected from their status and places control with a third party, with all the risks that entails. Even people with access to email and other relevant technology can be disconnected from their status if their details are not kept up to date.

Digital status also creates new, systemic security risks. If a person's physical proof of status is lost or stolen, the consequences, while very serious, are at least limited to that person. If the Government's digital status systems are compromised, either carelessly or maliciously, this could jeopardise the status of thousands or even millions of EU citizens. Other countries have experienced significant data breaches in large identity databases. In India, for example, the personal information of more than a billion Indian people leaked from the Government's Aadhaar database in 2018. ${ }^{137}$ Nor is the Home Office immune from such problems. In February 2021, for example, the Home Office admitted that offence records for 112,000 people had been inadvertently deleted from the Police National Computer, due to a 'coding mistake'. ${ }^{138}$ A similar mistake with digital status would be potentially disastrous.

Security is, again, a legitimate objective of a policy. But the early evidence shows that digital status, like physical documentation, can still be lost, stolen, or manipulated in a variety of ways. Moreover, as we discuss further below, the security objective does not justify the adoption of a policy which has discriminatory impacts and risks disconnecting people from their proof of lawful residence.

\footnotetext{
${ }^{131}$ Sajid Javid MP, Letter to Baroness Kennedy (20 March 2019); Immigration: EU Nationals: Written question - 237707 (1 April 2019).

${ }^{132}$ Ibid.

${ }^{133}$ House of Commons, Exiting the European Union Committee, above n 25, para 9; Immigration: EU Nationals: Written question - 237707 (1 April 2019).

${ }^{134} \mathrm{C}$ Barnard et al 'Unsettled status? Vulnerable EU citizens may lose their UK residence overnight' (LSE Brexit Blog, 27 November 2019).

${ }^{135}$ EU-Justice Sub-committee, Letter to Sajid Javid MP (27th February 2019).

${ }^{136}$ Barnard et al, above n 134 .

${ }^{137} \mathrm{M}$ Safi 'Personal data of a billion Indians sold online for $\mathfrak{E 6}$, report claims' (The Guardian, 4 January 2018), available at www.theguardian.com/world/2018/jan/04/india-national-id-database-data-leak-bought-online-aadhaar.

${ }^{138} \mathrm{~V}$ Dodd 'Home Office admits 15,000 people deleted from police records' (The Guardian, 8 February 2021), available at www.theguardian.com/uk-news/2021/feb/08/home-office-admits-15000-people-deleted-from-police-records.
} 


\section{(b) Less intrusive alternatives}

Our analysis is that the three main objectives of digital-only status - convenience, cost and security rest on problematic assumptions. We now turn to whether less intrusive measures could be used without unacceptably compromising the achievement of those objectives. Ultimately, it is for the Government to devise a functioning and lawful scheme for proof of immigration status. ${ }^{139}$ We do not attempt to devise any such scheme here. But in general terms, there is an obvious, less intrusive alternative to digital-only status: providing physical proof of status as a complement to digital status, at least for those people who would be particularly disadvantaged by digital-only status. For ease of reference, we call this 'the mixed model'. The mixed model raises several further design questions: whether the scheme would provide physical proof automatically to all status-holders, or only on application; whether an application-based scheme would be open to all, or limited to those with a qualifying reason; whether any application fee would be charged to defray some or all of the cost of the scheme (and if it should be waived where appropriate). We lack the space here to consider each of these questions in detail. If such a scheme were sensitively implemented, however, it would reduce the discriminatory effects of the current blanket policy, without unacceptably compromising the Home Office's objectives.

Turning first to the discriminatory effects, the mixed model would address the problems identified in the second part of this paper. It would protect people in the groups we have identified - disabled people, older people, and people from Gypsy, Roma or Traveller communities - from the particular disadvantages they are exposed to under a digital-only system. It would be much easier for them to prove their status, without the need for any internet infrastructure, hardware or digital literacy. And they would be less vulnerable to the lost benefits, additional burdens and distress which might flow from being unable to prove their status.

Nor would the mixed model unacceptably undermine the Home Office's objectives. Consider first the convenience objective. From the perspective of status-holders, the mixed model would be more convenient than digital-only status. Those status-holders who prefer digital status would be free to use it, while digitally excluded status-holders would enjoy the convenience of being able to rely on their physical status. It is possible that the mixed model would be less convenient for some third parties. ${ }^{140}$ But there are at least two reasons to doubt this claim. First, as discussed above, there are legitimate questions about whether digital status is in fact more convenient for third parties than physical status. Secondly, for third parties interacting with digitally excluded status-holders, the choice is not between physical proof and digital proof, but between physical proof and no proof at all.

Under the mixed model, the Government would incur the additional costs of producing physical proof of status for some or all EUSS applicants, depending on the design questions discussed above. But again, there is reason to doubt whether this would significantly increase the Government's overall costs. First, the Government could in principle charge a fee to recover some or all of this cost from applicants, subject to any additional concerns about accessibility or discrimination that this might raise. Secondly, by providing people with physical status, the Government would reduce the need for ongoing public expenditure on the support services discussed in the third part of this paper.

In relation to the security objective, on the available evidence it is difficult to say whether digital status or physical status is preferable. At the very least, the Home Office has provided no convincing evidence that digital-only status would provide better security overall than the mixed model. The key difference would be that, under the mixed model, digitally excluded groups would be able to rely on

\footnotetext{
${ }^{139}$ See eg R (Tigere) $v$ Secretary of State for Business, Innovation and Skills [2015] UKSC 57 at [64] (Lord Hughes) ('It is not for the court to devise such a scheme, but for the Secretary of State'); $R$ (Ward) $v$ London Borough of Hillingdon [2019] EWCA Civ 692 at [99] (Lewison LJ) ('It is not, of course, for the court to rewrite the policy').

${ }^{140}$ The Home Office has resisted calls for some form of physical status on this ground, arguing that ' $\mathrm{t}$ ] hird parties would have to continue dealing with physical documents, checking they are genuine, retaining copies to show that they have done so and generally requiring a more complex and bureaucratic process'. See Hansard HL Deb, vol 806, col 472, 5 October 2020.
} 
their physical status. But for such groups, the security benefits of digital status would be elusive. There is little point in a person's status being more secure from other people if they cannot use it themselves.

\section{(c) Does digital-only status strike a fair balance?}

The final limb of the Bank Mellat test requires a balancing of 'the severity of the measure's effects on the rights of the persons to whom it applies against the importance of the objective, to the extent that the measure will contribute to its achievement'. ${ }^{141}$ On our analysis, digital-only status clearly fails to strike a fair balance between the rights of individuals and the Home Office's objectives. ${ }^{142}$ It exposes people who cannot use digital status to very serious risks, including detention, denial of legal rights, and even deportation. And when compared to the mixed model, it promises only marginal and speculative benefits. It offers the possibility of greater convenience, but only for some third parties. It may save the Government some money, but only by shifting costs onto status-holders themselves. And the security benefits remain unproven.

\section{Conclusion}

The government's digital-only status policy - at least as it is being rolled out within the EUSS - is unlawful. It indirectly discriminates against a range of groups with protected characteristics, namely disability, age and race. There have been no effective steps taken to eliminate that discrimination, there are no compelling objectives which can justify the discrimination, and there are patently alternative, less intrusive options available. Managing migration and borders is a legitimate aim for states and governments should be exploring the use of technology to improve public services. But there is no legal entitlement to do so in a way which is unjustifiably discriminatory.

Though our analysis has been based in equality law, it reveals important defects in the general policy of digital-only status. Even if our legal conclusions are not accepted, the underlying systemic risks we have identified ought to be a continuing source of concern. The appropriate course now is for the policy to be reviewed and adjusted promptly. Without such action, the roots of digital discrimination in immigration policy and administration will be allowed to spread. They may quickly grow into another Windrush.

\footnotetext{
${ }^{141}$ Bank Mellat v HM Treasury (No 2) [2013] UKSC 39 at [74] (Lord Reed).

${ }^{142}$ See JT $v$ First-Tier Tribunal [2018] EWCA Civ 1735 at [83] (Leggatt LJ).
}

Cite this article: Tomlinson J, Maxwell J, Welsh A (2022). Discrimination in digital immigration status. Legal Studies 42, 315-334. https://doi.org/10.1017/lst.2021.33 